\title{
Asymptomatic submitral aneurysm: an uncommon complication of a common disease
}

\author{
G Vivek, ${ }^{1}$ Satish Nayak, ${ }^{2}$ Kushal Naha, ${ }^{2}$ Padmakumar Ramachandran ${ }^{1}$
}

${ }^{1}$ Department of Cardiology, Kasturba Medical College, Manipal University, Manipal, Karnataka, India

${ }^{2}$ Department of Medicine, Kasturba Medical College, Manipal University, Manipal, Karnataka, India

\section{Correspondence to}

Dr G Vivek,

vivekgraman@gmail.com
To cite: Vivek G, Nayak S, Naha $\mathrm{K}$, et al. BMJ Case Rep Published online:

[please include Day Month Year] doi:10.1136/bcr-2013200032

\section{DESCRIPTION}

A 60-year-old lady with type 2 diabetes was diagnosed with tuberculous pericardial effusion, and initiated on antitubercular therapy with isoniazid (300 mg oral), rifampicin (600 mg oral), pyrazinamide $(1250 \mathrm{mg}$ oral $)$ and ethambutol $(800 \mathrm{mg}$ oral) along with prednisolone (60 $\mathrm{mg}$ oral). On follow-up, transthoracic echocardiography confirmed resolution of pericardial effusion. A submitral aneurysm measuring $2.2 \times 1.8 \mathrm{~cm}$ was visualised just below the posterior mitral leaflet, and confirmed by transesophageal echocardiography. As the patient was asymptomatic and there was no evidence of mitral regurgitation, it was decided to keep her on regular follow-up (figure 1). Two years later she continues to be asymptomatic, with no echocardiographic evidence of disease progression.

Submitral aneurysms occur predominantly as congenital cardiac anomalies in indigenous Africans. ${ }^{1}$ Three anatomical types have been described, characterised respectively by a single localised neck, multiple necks and involvement of the entire posterior mitral annulus. ${ }^{1}$ Presence of a structurally weak membraneous submitral curtain has been proposed as a precursor to development of these aneurysms. ${ }^{2}$ Clinical presentations include cardiac failure consequent to associated mitral regurgitation, angina due to compression of the left coronary artery and thromboembolism. ${ }^{3}$ Symptomatic patients require surgical correction of the aneurysm with mitral valve replacement. ${ }^{4}$

Acquired submitral aneurysms have been previously reported in association with rheumatic carditis and tuberculosis. ${ }^{1}$ Our case lends further support to the role of tuberculosis in the pathogenesis of submitral aneurysms. Physicians should be aware of this unusual complication of tuberculosis as well as the possibility of underlying tuberculosis in non-African patients diagnosed with this anomaly.

\section{Learning points}

Submitral aneurysm is a rare but recognised complication of tuberculosis.

- Although typically manifested by heart failure, angina or embolic episodes, submitral aneurysms can be asymptomatic.

- Submitral aneurysms are rare in individuals of non-African ethnicity; when detected, they should immediately raise a suspicion of underlying tuberculosis.

Contributors SN, KN, GV and PR were involved in the concept, design, definition of intellectual content and literature search, and were in addition involved in the preparation, editing and review of the manuscript. GV and RP were involved in the clinical care of the patient.

Competing interests None.

Patient consent Obtained.

Provenance and peer review Not commissioned; externally peer reviewed.

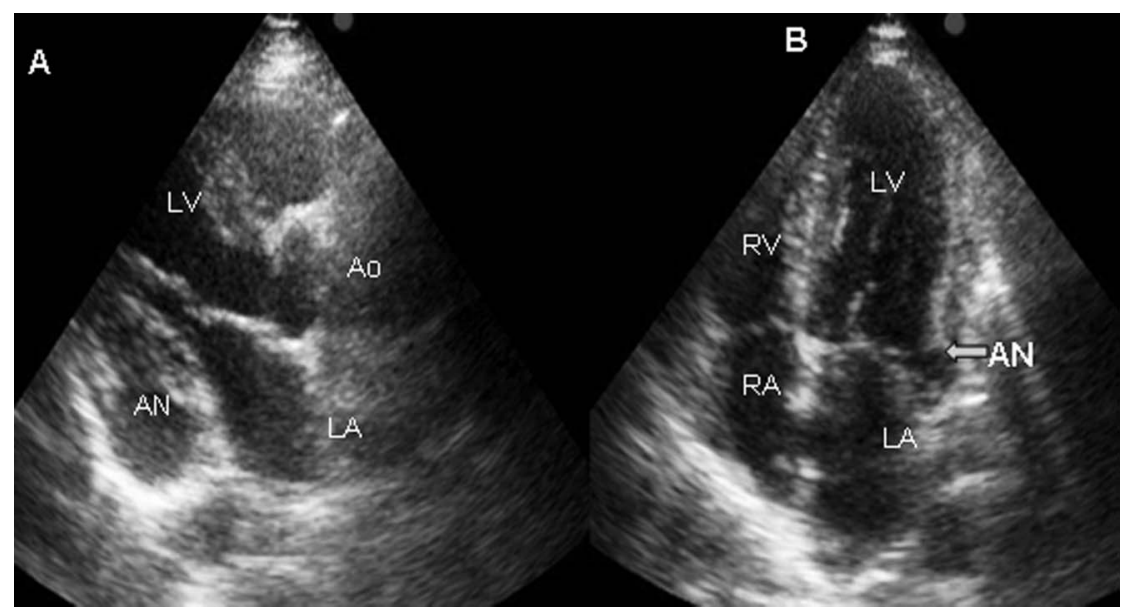

Figure 1 Transthoracic echocardiography parasternal long axis $(A)$ and 4-chamber view (B) showing the submitral aneurysm (arrow) in relation to the mitral valve. AN, submitral aneurysm; Ao, aorta; LA, left atrium; LV, left ventricle; $\mathrm{RA}$, right atrium; RV, right ventricle. 


\section{REFERENCES}

1 DuToit HJ, Von-Oppell UO, Hewitson J, et al. Left ventricular sub-valvar mitral aneurysms. Interact Cardiovasc Thorac Surg 2003;2:547-51.

2 Nayak VM, Victor S. Sub-mitral membranous curtain: a potential anatomical basis for congenital sub-mitral aneurysms. Ind J Thorac Cardiovasc Surg 2006;22:205-11.
3 Baruah DK, Kumar PVN, Reddy GSP, et al. Submitral aneurysm of the left ventricle. Indian Heart J 2012;64:77-9.

4 Chi NH, Yu HY, Chang $\mathrm{Cl}$, et al. Clinical surgical experience of congenital submitral left ventricular aneurysm. Thorac Cardiovasc Surg 2004;52:115-16.

Copyright 2013 BMJ Publishing Group. All rights reserved. For permission to reuse any of this content visit http://group.bmj.com/group/rights-licensing/permissions.

BMJ Case Report Fellows may re-use this article for personal use and teaching without any further permission.

Become a Fellow of BMJ Case Reports today and you can:

- Submit as many cases as you like

- Enjoy fast sympathetic peer review and rapid publication of accepted articles

- Access all the published articles

- Re-use any of the published material for personal use and teaching without further permission

For information on Institutional Fellowships contact consortiasales@bmjgroup.com

Visit casereports.bmj.com for more articles like this and to become a Fellow 